„Kwartalnik Filmowy” nr 113 (2021)

ISSN: 0452-9502 (Print) ISSN: 2719-2725 (Online)

https://doi.org/10.36744/kf.752

(c) Creative Commons BY-NC-ND 4.0

Grzegorz Nadgrodkiewicz

Instytut Sztuki, Polska Akademia Nauk

https://orcid.org/o000-0003-3091-5714

\title{
Onodrim z Fangornu
}

\author{
Słowa kluczowe: \\ Wiesław Juszczak
}

\author{
Abstrakt \\ Wspomnienie o Profesorze Wiesławie Juszczaku \\ (1932-2021).
}

Być może mniejszym grzechem jest zdradzić tajemnicę korespondencji po czyjejś śmierci niż za życia. Jeśli decyduję się częściowo tak tutaj uczynić (mea minutissima culpa?), to tylko dla ukazania splotu pewnych wątków późnej twórczości Wiesława Juszczaka z najwyżej przez Niego cenionym Władca Pierścieni. Dawno temu - choć nie według Tolkienowskiej miary czasu obejmującej kolejne ery Śródziemia, ale już na tym etapie ścieżki naukowej Juszczaka, gdy mniej Go interesowało tradycyjne uprawianie historii sztuki, bardziej zaś pociągała antropologiczna refleksja o realności bóstw, narodzinach mitologii i religiach archaicznych - Profesor drogą mailową zaproponował mi przejście na "ty”. Żartobliwie nazwał to za jednym ze swoich kolegów „per-TY-nencją”, co zapewne miało mnie ośmielić. Mimo to propozycją ze strony Mistrza (bądź co bądź schlebiającą młodemu doktorantowi) byłem zrazu speszony i nie odpowiadałem przez kilka dni, tym bardziej że w zakończeniu maila dodał: Proszę tylko: nie protestuj (np. ze względu na tzw. szacunek, o wieku nie mówiąc), bo zagrożę odsyłaniem listów! Od tego się zacznie! A jestem bardzo groźnym Onodrimem (czy Entem). Nie miałem wyjścia - musiałem (i chciałem) przystać na tę formę kontaktu, zwłaszcza wobec tak dobitnie zasygnalizowanego (pół żartem? pół metaforycznie?) tropu tolkienowskiego. 
Profesor odpisał (jak zawsze z adresu, nomen omen, onodrim@...): Dobrze, $\dot{z} e$ wreszcie zostałem "przyswojony", a potem - już jakby na innym poziomie porozumienia - odnosił się do różnych moich wątpliwości i zdradzał swoje credo: Ja w ogóle nie stucham wiadomości i nie zagladam do gazet. Oczywiście nie można się przed tym uchronić. Ale naprawdę (nie "tak naprawdę", jak się ostatnio przyjęło to w mowie i piśmie, choć to co innego znaczy) obchodza mnie - jak (zachowując proporcje w tym porównaniu) Gadamera i moja mistrzynię w zakresie badań nad religia grecka, Miss Jane Harrison - tylko takie rzeczy, które maja co najmniej 2000 lat, a nawet więcej, bo poczatek chrześcijańskiej ery, a nawet Platon, to już dla mnie "dzisiaj". Tylko tak można odnaleźć spokój i stąd też moja obsesyjna lektura "Władcy Pierścieni" czy "Mahabharaty"

Zatem Onodrim, Tolkien, Władca Pierścieni. To z pewnością niejedyny klucz pozwalający wejrzeć w głębię myśli Profesora Juszczaka ${ }^{1}$, ale w mym wspomnieniu ocalający Go najpełniej: jako niezwykłego uczonego, który u schyłku swej drogi naukowej dotarł do źródła, do mitycznego illo tempore, niejako stapiając się z tamtym czasem, przyjmując postać prastarego Drzewca czy Enta - by sięgnąć po tę „tożsamościową" metaforę Profesora. Ale przecież, dowodził Juszczak, takie metaforyczne postrzeganie trzeba w planie szerokim metodycznie podważać - jeśli chce się dociec prawdy najpierwszej, prawdy jako takiej, jako wartości, która czasem w sztuce objawia się przez piękno - i nie należy traktować spisanych mitologii jako wyłącznie bajek czy baśni, lecz widzieć w micie, w tym, o czym on mówi, samą przedwieczną realność 2 . Tak właśnie czyniąc, mógł Profesor posłużyć się Władca Pierścieni jako nie tylko - według określenia samego Tolkiena - esejem z zakresu lingwistyki (a już na pewno nie powieścią fantasy), ale przede wszystkim jako re-kreacją archaicznej opowieści, gdy pisał obszerne wprowadzenie do Archeologii mitu, czyli drugiej części Pani na żurawiach, swego opus magnum. W tych wstępnych rozważaniach o języku mitu Tolkien (zaraz obok Owena Barfielda, autora Poetic Diction) powraca wielokrotnie jako „prawodawca” owego sposobu myślenia, który pozwolił Juszczakowi konstatować, że także współczesność może mieć (i w postaci Władcy Pierścieni właśnie ma) swą narrację mityczną pieśń odwieczna, epos archaiczny, acz podany na nowo.

Co więcej, ten rodzaj literackiego ucieleśnienia energii mitycznej (mitycznego niewysłowienia czy objawienia pierwotnego), ukonkretniającej się w pradawnym modelu emocjonalnego ogarniania świata, nosi cechy szczególnej epifanii, ponieważ w tajemny sposób objawia się w nim jakaś intuicyjnie wyczuwalna prawda nadrzędna. Czym by ona była? Juszczak sugeruje tutaj wpływ boskiego natchnienia, przypominając o liście jezuity Roberta Murraya, który po przeczytaniu części "The Lord of the Rings" napisat do Tolkiena, że dzieło wywołało w nim poczucie "wielkiej zgodności ze stanem Łaski"3. W tym sensie wnikanie w przestrzeń mitu (jej enklawami w Tolkienowskim świecie są choćby Rivendell czy Las Fangorn) byłoby - jak chce Profesor - wkraczaniem w epifanię, gdzie panuje realność mityczna: Nic nie podlega tu zmianie, pradawność wciaż objawia swa petnię. Mit pozostaje nienaruszony i stanowi niejako codzienny tryb myślenia mieszkańców tych krain, które jeszcze nie wyszły poza legendę lub - choć do niej należa w innych kategoriach zachowaty to życie, które poza nimi przemienia się w pieśń, przypominana gdzie indziej tylko niekied $y^{4}$.

Pisarstwo Tolkiena poznałem późno. Dopiero dwadzieścia lat temu $u^{5}$ - wyznawał Juszczak w 2002 r. Być może ta „dojrzała inicjacja” dała Profesorowi szansę za- 
czerpnięcia z Tolkiena samej esencji? Jeśli tak, byłaby nią zapewne idea „wtórstwarzania” (wtórnego odtwarzania), która w istotny sposób podbudowała jego koncepcję archeologii mitu. O Tolkienie ożywiającym światy pradawne pisał: (...) nie tworzyt "swobodnie". Nie notowat własnych rojeń podsuwanych mu przez wolna od jakichkolwiek więzów imaginacje, ale rekonstruował pewien konkretny świat z możliwie najwierniejszego ogladu źródet, zawierających po części wyraźne, po części już na wpót tylko czytelne fragmenty jego odległych konturów i detali, poddawane nacechowanemu akrybia, choć zawsze "wtórnemu" - wedle jego deklaracji - tworzeniu, albo odtwarzaniu ${ }^{6}$. W przypisie zaś dodawał, że w korespondencji Tolkien często wspominał o szczególnym poczuciu, jakby proces pisania nad nim panował (Kiedy się rozpędzam, rzecz zdaje się pisać sama, jakby wtedy wychodziła na jaw prawda, jedynie niedokładnie dostrzegana we wstępnym szkicu ${ }^{7}$ ), a w ukończonym utworze słychać było echa sprawczości spoza tego świata (Żaden człowiek nie może wydać pewnego sądu o własnym rozsądku. Jeśli w jego dziele zamieszkuje świętość lub też rozświetla je ona jako przenikajace przezeń światło, to nie pochodzi ona od tego człowieka, lecz [zjawia się] poprzez niego ${ }^{8}$ ). Juszczak żywił przekonanie, że Tolkien - bard czy wykonawca opowieści cyklicznej, a zarazem subcreatore („,stwórca pomniejszony") - przemawiat z innej epoki niż nasza i jakby żył w innym czasie $e^{9}$. Widział go zatem jako pokornego redaktora mitu (twórcę nowożytnego eposu, choć de facto odtwórcę ogromnej zbiorowej pieśni), pracującego w stużbie tej Sity, za przyczyna której zjawiają się obrazy "odzwierciedlające fragmenty wiecznej prawdy”, "refleksy prawdziwego światła” rozszczepione w zmysłowym oku człowieka ${ }^{10}$, zaś sam mit - już w ślad za Tolkienem, śmiało przykładającym tę kategorię do Ewangelii - jako formę objawienia. Człowiek jako subkreator jest zaledwie wyrazicielem, nie zaś autorem tych treści objawionych - jedynie w natchnieniu przyobleka w słowa pierwotny „niemy" mit.

Może się wydawać, że przytaczając te mitologiczne egzegezy Juszczaka, usuwam Go w cień rzucany przez Tolkiena czy że jego myśl oryginalną przesłaniam rozpoznaniami autora Władcy Pierścieni. Tak nie jest. Chcę raczej wskazać tę prymarną Tolkienowską ideę, w której Profesor odnalazł głęboki sens, pozwalający mu potem, na kartach Archeologii mitu, rozprawiać o mocach podziemnego świata, rekonstruować teologiczne podstawy tragedii, rozpoznawać postacie apokryfu czy wreszcie odsłaniać tajemnice kultu Persefony i Demeter w misteriach eleuzyjskich - słowem: doświadczać realności mitu. A może jednak, mimo wszystko, pozostawia Go to w mym wspomnieniu nadal w cieniu Tolkiena? Poniekąd chcę, żeby tak było, bo być może chciał tego sam Profesor. Gdy w zakończeniu wspomnianego wprowadzenia stwierdzał, że o języku mitu da się powiedzieć coś naprawdę istotnego jedynie językiem mitu, uciekał się do znamiennego cytatu: Entowie, trzeba wiedzieć, też bywaja różni. Istnieją także inne stworzenia, które wygladaja podobnie jak entowie, a wcale entami nie są. (...) Ale mojego prawdziwego imienia wam nie wyjawie, przynajmniej jeszcze nie teraz. (...) Przede wszystkim to jest bardzo dtugie imie, bo rosto $z$ czasem, a że bardzo, bardzo długo żyje, więc urosto do całej historii. W moim języku, $w$ starej mowie entów, jak wy byście go nazwali, imię zawsze zawiera historię tego, kto je nosi. To bardzo piękny język, ale trzeba mieć dużo czasu, żeby nim coś powiedzieć, bo my mówimy naszym językiem tylko o tym, co warto bardzo dtugo opowiadać i czego warto bardzo długo stuchaćn ${ }^{11}$. Passus ten oczywiście służył wywodowi Juszczaka w sensie ścisłym, będąc niejako podaną językiem literackim wykładnią materii mitu, ale w konwencji wspomnieniowej można go też przenieść w inne, bardziej już meta- 
foryczne rejestry i prawem licencji poetyckiej utrwalić dzięki niemu pamięć o Profesorze jako Onodrimie.

Jak wiemy z Władcy Pierścieni, Entowie (Enty; w sindarińskim: Onodrimowie czy Enydzi) byli przedstawicielami najstarszego plemienia, które przetrwało do Trzeciej Ery - długowiecznymi istotami przypominającymi drzewa. Nazywano ich pasterzami drzew, bo się nimi - podług podobieństwa do konkretnego gatunku - opiekowali. Żyli w swoim niespiesznym rytmie, z dala od zgiełku świata, zanurzeni w leśną realność mityczną gdzie - przypomnę za Juszczakiem - pradawność wciąż objawia swa petnię. Nie umierali, tylko drzewieli - przestawali mówić i się poruszać. W Trzeciej Erze już tylko Las Fangorn był ich ostoją. Drzewiec, najstarszy z nich i przywódca rasy Onodrimów, dawał czasem hobbitom zasmakować starożytnego języka Elfów Wysokiego Rodu, którego słowa Entowie lubili wplatać w swą tajemną mowę. Lecz choć Meriadok Brandybuck i Peregrin Tuk słyszeli od Drzewca: Taurelilomëa-tumbalemorna Tumbaletaurea Lomeanor, to zupełnie nie rozumieli, że chodzi o Wielolesistycienisty głębokodolinnoczarny głębokodolinnoleśny mrocznykraj, co się wykłada jako: czarny cień leży w głębokich dolinach lasu ${ }^{12}$. Nie rozumieli, bo Onodrimowie stworzyli sobie język niepodobny do wszystkich innych, powolny, górnolotny, pełen zlepków stów i powtórzeń, doprawdy wymagający głębokiego oddechu; ukształtowany z różnorodnych odcieni samogłosek, akcentów, długości, język tak zawiły, $\dot{z} e$ nawet uczeni Eldarowie nie próbowali go przedstawić w piśmie. Enty używały swego języka tylko między soba, nie potrzebowały go jednak otaczać tajemnica, bo nikt prócz nich nie mógł się i tak tej niezwykłej mowy nauczyć13. Niezwykłej mowy Wiesława Juszczaka również nie sposób się nauczyć. To bowiem mowa mędrca - jednego z najwybitniejszych polskich humanistów, historyka sztuki, który jednak w swej kilkudziesięcioletniej pracy badawczej i pisarskiej objawiał się także jako wielkiego formatu teoretyk sztuki i jej natchniony filozof, tłumacz, znawca filmu, literatury i muzyki, w szczególności sztuki operowej. Jest to zarazem mowa kogoś wyjątkowego, przychodzącego jakby sprzed czasu, kogoś, kto w swe dzieło wpisał w pewnym sensie także siebie samego. To intrygujące zapętlenie stanie się jaśniejsze, gdy powtórzy się słowa Onodrima pozwalające widzieć czyjeś życie oraz imię jako wymowna, niemal mityczną jedność: W moim języku, w starej mowie entów, (...) imię zawsze zawiera historię tego, kto je nosi.

\footnotetext{
${ }^{1}$ Naukowe oeuvre Wiesława Juszczaka zostało solennie przedstawione na łamach „Kontekstów. Polskiej Sztuki Ludowej": w dziale dokumentującym przyznanie Profesorowi w 2010 r. Nagrody Polskiego PEN Clubu im. Ksawerego Pruszyńskiego (nr 2-3, 2010) oraz w relacji z jubileuszu Jego osiemdziesięciolecia w 2012 r. w Instytucie Sztuki PAN i laudacjach z okazji odnowienia doktoratu na Uniwersytecie Warszawskim w 2013 r. (nr 1, 2013). Również zamieszczone w tym tomie „Kwartalnika Filmowego" wspomnienia Urszuli Makowskiej i Tadeusza Szczepańskiego doskonale zdają sprawę z interdyscyplinarności dzieła polihistora Juszczaka - Wielkiego Maga i Egze-
}

gety nauki polskiej, jak określił go Waldemar Okoń („Konteksty” 2013, nr 1, s. 12). Wobec tak solidnej dokumentacji dokonanej przez innych czuję się zwolniony z czysto kronikarskiego obowiązku.

2 Por. W. Juszczak, Pani na żurawiach. Czesść pierwsza: Realność bogów, Wydawnictwo Aureus, Kraków 2002.

${ }^{3}$ Tenże, Pani na żurawiach. Część druga: Archeologia mitu, Wydawnictwo Aureus, Kraków 2012, s. 56.

${ }^{4}$ Tenże, „Władca Pierścieni": „zmyślenie” i prawda?, w: tegoż, Wędrówka do źródet, słowo/obraz terytoria, Gdańsk 2009, s. 546 (rozbudowana i poprawiona wersja artykułu opub- 
likowanego pierwotnie, pod tym samym tytułem, w ,Tygodniku Powszechnym" 2002, nr 11, s. 8-9).

${ }^{5}$ Tamże, s. 536.

${ }^{6}$ W. Juszczak, Pani na żurawiach... dz. cyt., s. $29-30$.

7 Tamże, s. 30 .

8 Tamże.

${ }^{9}$ W. Juszczak, „Władca Pierścieni”... dz. cyt., s. 543 .

${ }^{10}$ Tamże.
${ }^{11}$ J. R. R. Tolkien, Władca Pierścieni: Dwie wieże, tłum. M. Skibniewska, Warszawskie Wydawnictwo Literackie MUZA SA, Warszawa 2012, s. 68.

${ }^{12}$ Tenże, Władca Pierścieni: Powrót króla. Dodatki, tłum. M. Skibniewska, Warszawskie Wydawnictwo Literackie MUZA SA, Warszawa 2012, s. 445.

13 Tamże.

\section{Grzegorz Nadgrodkiewicz}

Filmoznawca, absolwent kulturoznawstwa ze specjalnością filmoznawczą na Uniwersytecie Łódzkim. Pracuje w Zakładzie Antropologii Kultury, Filmu i Sztuki Audiowizualnej w Instytucie Sztuki Polskiej Akademii Nauk. Sekretarz redakcji „Kwartalnika Filmowego” oraz członek Rady Naukowej „Pleografu. Kwartalnika Akademii Polskiego Filmu”. Członek Polskiego Towarzystwa Badań nad Filmem i Mediami. W kręgu jego zainteresowań badawczych znajduje się m.in. film religijny i biblijny, kwestie duchowości w kinie oraz zagadnienia dotyczące związków filmu i teatru. Artykuły naukowe i przekłady publikował m.in. w „Kwartalniku Filmowym”, „Kontekstach” oraz tomach zbiorowych.

\title{
Bibliografia
}

Juszczak, W. (2002). Pani na żuraziach. Część pieræesza: Realność bogów. Kraków: Wydawnictwo Aureus.

Juszczak, W. (2009). „Władca Pierścieni”: „zmyślenie” i prawda?. W: W. Juszczak, Węrówka do źródeł (ss. 535-547). Gdańsk: słowo/obraz terytoria.

Juszczak, W. (2012). Pani na żurawiach. Cześśc druga: Archeologia mitu. Kraków: Wydawnictwo Aureus.

Tolkien, J. R. R. (2012). Władca Pierścieni: Dwie wieże (thum. M. Skibniewska). Warszawa: Warszawskie Wydawnictwo Literackie MUZA SA.

Tolkien, J. R. R. (2012). Władca Pierścieni: Powrót króla. Dodatki (tłum. M. Skibniewska). Warszawa: Warszawskie Wydawnictwo Literackie MUZA SA.

\author{
Keywords: \\ Wiesław Juszczak \\ Abstract \\ Grzegorz Nadgrodkiewicz \\ Onodrim of Fangorn \\ A Memory of Professor Wiesław Juszczak (1932-2021).
}

